\title{
Global Cooperation in Combating Sea Piracy: The Factors behind Global Piracy Trends
}

\author{
Radillah Khaerany \\ School of Law, University of Leeds \\ The Liberty Building, Leeds, LS2 9JT, United Kingdom \\ Tel./Fax: +44-0-113-343-5033 E-mail: khaeranyradillah@gmail.com \\ Maskun \\ Faculty of Law, Hasanuddin University \\ Jl. Perintis Kemerdekaan KM. 10, Tamalanrea, Makassar, Indonesia \\ Tel./Fax: +62-411-587219 E-mail: maskunlawschool@yahoo.co.id \\ Submitted: Jun 16, 2016; Reviewed: Jul 3, 2016; Accepted: Aug 11, 2016
}

\begin{abstract}
The rising number of sea travel is followed by the emerging number of sea crimes such as sea piracy and maritime terrorism. In recent two decades, the number of crimes on the sea have shown an alarming figure, where areas with a dense traffic of vessels such as the Gulf of Aden and Malacca Strait becomes the hot spots for piracy crime. The main reason behind the emerging of modern piracy is the increasing number of sea transported goods which create a significant opportunity to be a huge target of crime considering the drives behind piracy is financial reason. Some area of sea piracy took place commonly in Africa and Southeast Asia.
\end{abstract}

Keywords: Global Cooperation, Combating Sea Piracy

DOI: http://dx.doi.org/10.20956/halrev.v1n2.305

\section{INTRODUCTION}

The intense global movement nowadays has brought people as well as goods to travel around the world through road, air, and sea. In purpose of trading and transporting goods, travel by sea has been a primary mode of transportation since long time ago. The rising number of sea travel is followed by the emerging number of sea crimes such as sea piracy and maritime terrorism.

In recent two decades, the number of crimes on the sea have shown an alarming figure, where areas with a dense traffic of vessels such as the Gulf of Aden and Malacca Strait becomes the hot spots for piracy crime. However, in past five years, the number of piracy attack has shown a declination in many places, e.g. Gulf of Aden, that many scholars believe is caused by several factors such as international or regional cooperation in anti-piracy operation and precautionary safety action which taken by ships owner.

In contrast, the growing number of piratical attacks is experienced by South- 
east Asia region in this recent five years. Countries' lack of maritime security and the absence of private maritime security guard are suspected as the reason behind this phenomenon. By studying the factors behind the different trends of piracy number between Africa and Southeast Asia, it can help us to comprehend the role of international cooperation in combating piracy as transnational crime.

\section{ANALYSIS AND DISCUSSION}

\section{The Inconsistency on Defining Piracy}

Sea piracy is not a new thing in the nautical world. It has been existed and transformed from mugged towards small merchantmen performed by poor people in the coastal area to numbers of organized attack towards tanker vessel that happened this recent decade around Malay Archipelago ${ }^{1}$. Piracy itself has numbers of different definitions in international world. Some organizations, such as International Maritime Organization (hereafter IMO) and International Maritime Bureau (hereafter IMB) for example, defined piracy distinctively.

IMO, in parallel with Article 101 of the United Nations Convention on the Law of the Sea (UNCLOS), emphasized that piracy should be taken place in international sea territory to distinct it with armed robbery that occurred within any country's territory. ${ }^{2}$ In contrast, IMB does not give any prerequisite about the location of the crime. Both of organizations also have differently formulated the motive of the piracy, which according to IMO should be private goals,

Philip Gosse. (2012). The History of Piracy. New York: Courier Corporation.

UNCLOS, 1982, p. 57 and according to IMB, it also includes attack based on political or environmental aims that are identical to maritime terrorism.

The differentiation of definition between piracy and maritime terrorism was criticized by Gerrard-Ong ${ }^{3}$, who believed that the line between two crimes has been blurred by the involvement of violence in both offenses. Despite the similarity in crime method that involve violent, both crimes has different characteristic and threats. Therefore, a distinction should be made to clarify the difference and the further discourse about security response that required in order to tackling the problem.

These inconsistencies on defining piracy amongst international organizations inflict difficulty in both research and practical field such as policy-making process to combat sea piracy. The gap between de facto definition of piracy that has been publically recognized and de jure definition that promulgated by UNCLOS undeniably impacted this research and deliverance of the result. In attempt to tackle this problem, the discussion on piracy in this essay will refer to piratical act that occurred both in countries' territory and international water considering the available data that provided by IMB is compiled undividedly on piracy and non-piracy category of attack.

\section{Types and Methods of Piracy}

On 28 May 2014, a Thai-flagged tanker laden, MT Orapin, was attacked and hijacked by

\footnotetext{
Gerrard Ong, G. (2005). Ship's can be dangerous, too: coupling piracy and terrorism in Southeast Asia's maritime security framework. In: Derek Johnson and Mark Valencia (eds). (2005). Piracy in Southeast Asia: Status, Issues, and Responses. Singapore: Institute of Southeast Asian Studies Publishing.
} 
armed pirates near Bintan Island, Indonesia after departed from Singapore to Pontianak. Report was received by IMB after the Owner was not able to contact the tanker. On $1^{\text {st }}$ June, the tanker arrived in Sriracha port, Thailand, where the crew informed the authority that they had been hijacked, and the cargo was stolen. The pirates also damaged the communication equipment of the tanker before abandoned it. ${ }^{4}$ Attack towards ship that followed by hijacking to unload its cargo such what happened to MT Orapin is a common type of piracy act.

According to Abhyankar ${ }^{5}$, type of piracy can be seen on the purpose of the act that has connection with the use of violence as their force. If the piracy is targeting the cargo to steal, the degree of violence that involved is higher than the piracy with target of cash or other valuable objects that belong to the crew or the ship that tends to involves minimum violent. The type of piracy also can be identified by the actors and their piratical act $^{6}$ where each region with high piracy rates has its characteristic. The pirates in Horn of Africa work in well-organized operation, Nigeria is more violent with kidnap involvement, and Southeast Asis's pirates commonly performed petty crime type of piracy.

According to Bateman, there are at least three types of piracy that exist nowadays. First, hijacking type of piracy where the

4 Maritime Security Review, 2014.

5 Abhyankar, J. (2006". Piracy, armed robbery, and terrorism at sea: a global and regional outlook. In: Ong-Webb, G. G. ed. Piracy, Maritime Terrorism, and Securing the Malacca Straits. Singapore: Institute of Southeast Asian Studies Publishing.

6 Bateman, S. (2010). "Maritime piracy in the Indo-Pacific region-ship vulnerability issues". Maritime Policy \& Management, 37(7): 737-751. pirates hijack a vessel and captive its crew in order to asking ransom for exchange from the company that owns the ship. This type of piracy is likely to be successful since most companies prefer to pay, as it is usually covered by insurance, to avoid bad publication and further investigation that may cause more loss ${ }^{7}$. The second type is piracy towards sailing ship in purpose to seize money and any other valuable items which commonly conducted with slight involvement of violence. The last type of piracy is hijacking and stealing of vessel in order to confiscate its precious cargo such as crude oil as well as the ship. The cargo will then sold to a new buyer and the ship is going to be repainted, renamed, and reregistered under different nationality as it is known as "phantom ships". ${ }^{8}$

In discussing maritime piracy in global framework, many scholars deliver their discourse by making division based on area where the highest number of piracy are taking place, i.e. Southeast Asia with Malacca Strait in particular and Africa especially on the Horn of Africa or off Somalia's shore and Nigeria water. This territorial-based division aims to simplify the discussion and to find out each characteristic of piracy crime in both areas that will be useful for further strategy to combat it.

\section{Motives and Causation}

The main reason behind the emerging of

7 Foster, B., (2014). "Modern maritime piracy: An overview of Somali piracy, Gulf of Guinea piracy and South East Asian piracy". British Journal of Economics, Management \& Trade, 4(8): 1251-72. Young, A. J. 2007. Contemporary Maritime Piracy in Southeast Asia. Singapore: Institute of Southeast Asian Studies Publishing. 
modern piracy, according to Rosenberg 9 , is the increasing number of sea transported goods which create a significant opportunity to be a huge target of crime considering the drives behind piracy is financial reason. However, many scholars believe that the causative elements of the rise of piracy crime are "complex and multifaceted" 10 . It also caused by some factors that nurturing the continuity of piracy as a crime, such as countries' incompetency on combating the crime $^{11}$; which created a "permissive political and legal environment", ${ }^{12}$ inadequate protection of the $\operatorname{ship}^{13}$, and deficiency in economic opportunity of one country. ${ }^{14}$

On the other hand, ship owners are also playing a role in maintaining the existence of piracy due to their submission in paying ransom for the hijacked vessels which often conducted privately to avoid adverse publication ${ }^{15}$. Reflected from those various numbers of different factors which underlie the modern piracy, it is possible that each area has its unique causation factor behind the piratical act that taken place there. Considering the fact that each area has different type of piracy crime, it supposed the discussion on causative factors will be conducted according to the area.

Rosenberg, D., 2009. "The political economy of piracy in the South China Sea". Naval War College Review, 62(3): 43-58.

10 Chalk, P. (2009). "Piracy off the horn of Africa: scope, dimensions, causes and responses". Brown J. World Aff., 16, p.89.

11 Gagain, M., (2010). "Neglected Waters: Territorial Maritime Piracy and Developing States: Somalia, Nigeria, and Indonesia". New Eng. J. Int'l \& Comp. L., 16, p.169.

12 Daxecker, U. and Prins, B. (2013). "Insurgents of the Sea Institutional and Economic Opportunities for Maritime Piracy". Journal of Conflict Resolution, 57(6): 940-965.

13 Bateman, S. Op.Cit.

14 Daxecker, U. and Prins, B. Op.Cit. p.4

15 Chalk and Hansen. Op.Cit.

\section{Africa}

Majority of the piracy and armed robbery attacks in Africa occurred in the Gulf of Aden, off Nigeria, and off Somalia or as known as Horn of Africa. According to the annual report that published by $\mathrm{IMB}^{16}$, most piracy and armed robbery attacks that occurred in Africa water initiated by Somali pirates with its spreading covers Gulf of Aden, Red Sea, Somalia water, and the Arabian Sea. The high number of sea pirates that originated from Somalia is believed to be a depiction of the in-land turmoil that the country experienced ${ }^{17}$. Civil war that leads to government inability to enforce law is being exacerbated by poverty that has been struck the country for years. Being in the situation where the government cannot provide basic needs, it is a foreseeable outcome that many Somali shift their occupation to a criminal career. This condition of void governance and all the scrutiny that it caused can be argued as the primary factor of piracy rise in Somalia.

\section{Southeast Asia}

As one of the places with the highest intensity of ship traffic, Southeast Asia is holding a reputation as piracy and armed robbery hotspot with most act occurred around Strait of Malacca, Singapore Strait, and South China Sea. Strait of Malacca is a sea lane with approximately 900 kilometers long which located in the middle between Indonesia, Malaysia, and Singapore is a major trade hub that is connecting Indian Ocean and South China Sea. Along with the high numbers of vessel travel through

16 Annual Report IMB, 2014.

17 Chalk and Hanses. Op.Cit. 
Table 1. Global piracy: actual and attempted piracy attack in different regions, 2004-2014.

\begin{tabular}{lccccccccccc}
\hline \multicolumn{1}{c}{ Locations } & $\mathbf{2 0 0 4}$ & $\mathbf{2 0 0 5}$ & $\mathbf{2 0 0 6}$ & $\mathbf{2 0 0 7}$ & $\mathbf{2 0 0 8}$ & $\mathbf{2 0 0 9}$ & $\mathbf{2 0 1 0}$ & $\mathbf{2 0 1 1}$ & $\mathbf{2 0 1 2}$ & $\mathbf{2 0 1 3}$ & $\mathbf{2 0 1 4}$ \\
\hline Southeast Asia & 158 & 102 & 83 & 70 & 54 & 47 & 70 & 80 & 104 & 128 & 141 \\
Far East & 15 & 20 & 5 & 10 & 11 & 22 & 44 & 23 & 7 & 13 & 8 \\
Indian Sub-continent & 32 & 36 & 53 & 30 & 23 & 30 & 29 & 16 & 19 & 26 & 34 \\
South America & $45^{*}$ & 25 & 29 & 21 & 14 & 37 & 40 & 25 & 17 & 18 & 5 \\
Africa & 71 & 80 & 61 & 120 & 189 & 266 & 259 & 293 & 150 & 79 & 55 \\
Rest of World & 8 & 13 & 8 & 12 & 3 & 8 & 4 & 2 & 0 & 0 & 2 \\
$\quad$ Total at year end & 329 & 276 & 239 & 263 & 293 & 410 & 445 & 439 & 297 & 264 & 245 \\
\hline
\end{tabular}

* Including one case from USA, as the 2006 report put America region instead of South America as in 2010 and 2014 report. Notes: the report was based on countries where the piracy and armed robbery occurred and the countries classified by regions. Vietnam and South China Sea were listed as part of Far East Region even though the actual location is in Southeast Asia. Source: International Chamber of Commerce, IMB, Piracy and Armed Robbery against Ships Annual Report, 2006, $2010,2014$.

this waterway the risk of it to be congested is also increase and thus, followed by crime such as piracy. ${ }^{18}$

Slightly different from Somalia who experience political instability that led to the increasing of crime, political environment of countries around Malacca Strait is considerably stable during the years when the number of piracy climb. Young tried to elaborate this phenomenon by examined it through state control perspective that lead him to conclusion that state inability to combat and prosecute crime that occurred in its territorial is the main cause ${ }^{19}$. Besides that, the geographical condition of Strait of Malacca that surrounded with a lot of small islands is also a supporting factor as it assembles a strategic haven for the pirates and creates difficulties for the security officer to spot their hiding place.

\section{Piracy's Global Rates}

Piracy is one of the crimes which believed to be underreported. The fact that vessels

\footnotetext{
18 Rosenberg, 2009. Op.Cit.

19 Young. Op.Cit.
}

that transported valuable goods are covered by insurance with high premium, it makes any sign of it being targeted for piracy will raise the premium even higher. Thus, the data of piracy is based on report that voluntarily delivered by the ship owner. One of document that record the number of global sea piracy report is the annual report on piracy and armed robbery attacked that published by IMB in cooperation with International Chamber of Commerce (ICC). This document contains with statistic of reported actual and attempted piracy and armed robbery that occurred around the world.

In Table 1 above, it can be seen that the number of piracy in recent ten years shows different trends according to the region where it was occurred. The number of actual and attempted piracy attack in Southeast Asia has continued to grow in recent five years despite the major drop of global rates at the same period of time. The numbers of recorded actual and attempted piracy attack that located in this region in 2004 shown 
Chart 1. The piracy hot spots: actual and attempted piracy attack trends in Southeast Asia, Africa, and the world in total, 2004-2014.

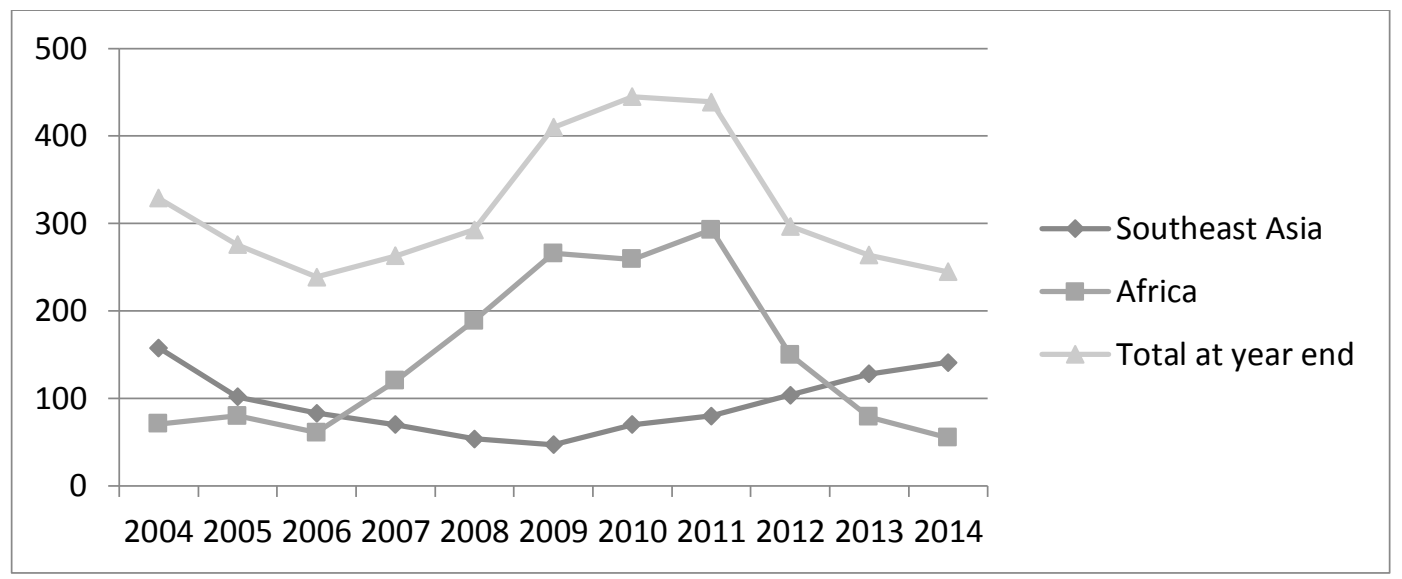

Source: International Chamber of Commerce, IMB, Piracy and Armed Robbery against Ships Annual Report, 2006, 2010, 2014.

a decreased from 158 to 47 in 2009 . The number then continued with a rise to 141 attacks or attempt of attacks in 2014.

In contrast, the reported attack in Africa, where the Gulf of Aden and Somalia as the two hot spots of piracy shows a continuous decline after 2011. The rate of piracy in Africa shows almost identical trend to the global rate with a gradual climb from 2006 to 2009. The global rate was started to declining after that from 445 actual and attempted piracy attacks to 245 in 2014 . The dramatic drop of piracy in Africa began a year later with 293 attacks in 2010 with more than $500 \%$ drop to 55 attacks in 2014. The contrasting figures that shown by the data between these two regions raise a question on what factors that lead to these results.

\section{Piracy in Africa and Southeast Asia}

Based on the opposite trends that illustrated by Africa and Southeast Asia data on total piracy number during one 2004 to 2014, the discussion will be continued to the factors behind the piracy drop in Africa and the climb in Southeast Asia. Generally, there are numbers of hypothesis to explain the crime drop phenomenon that has been started in the beginning of 1990s. One of those theories is security hypothesis which emphasizes on how the change in security may results decreasing number of crime. ${ }^{20}$ The security hypothesis has a close relation to the situational crime prevention theory that suggests to reduce crime by minimizing the offender opportunity trough changes in some significant aspects that will create the target hardening situation ${ }^{21}$. However, it might be too early to conclude that the drop of global piracy number is caused by the crime preventive measures that have increased the security on the piracy hotbeds. For the beginning, this part will discuss the antipiracy actions that have been implemented both in Africa and Southeast Asia.

The high intensity of sea piracy world wide has brought huge damage not only for

\footnotetext{
20 Farrell, G., Tilley, N. and Tseloni, A. (2014). Why the Crime Drop?. Why Crime Rates Fall and Why They Don't, p. 43.

21 Clarke, R.V. (1983). Situational crime prevention: Its theoretical basis and practical scope. Crime and justice, pp. 225-256.
} 
property but also people's life. Since piracy in modern world today is involving many countries, i.e. countries where the crime is taking place and countries where the vessel originated and bears the flag, it has raised global concern and cooperation to fight it. Mutual concern was built between countries which lead to decision to take necessary measure to combat this crime. The anti-piracy policy was created under cooperation between countries in regional and international basis. Therefore, each policy and measure has its own characteristic that has been adjusted according to the type of piracy that occurred in that area.

In international framework, there are at least two international legal instruments, UNCLOS 1982 and the Convention for the Suppression of Unlawful Acts against the Safety of Maritime Navigation 1988 that has been established to set up the rules on how country should make commitment to combat sea piracy either individually or in cooperation with another country. However, in practice, the effort to fight this crime is all depends on the country policy considering many piracy attacks occurred in the territory water or the Economic Exclusive Zone of a country. For example, piracy attacks that taking place in Gulf of Guinea are mostly occurred in Nigerian water ${ }^{22}$ and thus the responsibility of enforcement is in Nigeria authority's hands and any foreign involvement must have permission from them. $^{23}$

22 Orji, U.J. (2013). "Tackling Piracy and Other Illegal Activities in Nigerian Waters". Journal of Defense Resources Management, 2: 65-70.

23 Munson, M. 2013. Nigeria is Not Somalia-Look for Pirates Somewhere Else. http://warontherocks. com/2013/12/nigeria-is-not-somalia-look-for-piratessomewhere-else/ (December 25, 2015).

\section{The declining number of piracy in Africa}

Before the discussion moving to the antipiracy measures that might attributed to the decline of piracy in Africa, it is important to identify the difference between piracy attacks that taking place in Nigeria and Somalia. First of all, the huge drop of this region is mainly experienced by Somalia with 160 reports in 2011 to 3 in $2014 .^{24}$ The same trends are also shown by areas where, according to IMB, its piracy acts are conducted by Somali pirates such as Gulf of Aden and Red Sea.

On the other hand, Nigeria piracy was increase during 2010 to 2013 from 19 reports to 31 then decline by almost a half with 18 reports in 2014. Second of all, the piratical actions that occurred around the Horn of Africa were mostly taking place in high water ${ }^{25}$; meanwhile the attacks that recorded in Nigeria were located in its territorial water or the EEZ. The question of why the piracy crime drop in the Gulf of Aden and off the Horn of Africa was not followed by the Gulf of Guinea, according to Munson, is because the. maritime cooperation in that area is hindered by the sovereignty concern of Nigeria who is reluctant to permit foreign security intervention. ${ }^{26}$

The initiative of international cooperation in countering piracy off the Horn of Africa was based on the request letter from the Transitional Federal Government (TGF) of Somalia for international assistance to address the issue. ${ }^{27}$ The North Atlantic Organization Treaty (NATO), by the request from UN Secretary General, created the Operation Allied Provider with the initial aim to escort

24 International Maritime Bureau, 2014.

25 Munson. Op.Cit.

26 International Crisis Group, 2012.

27 United Nation Security Council, 2008 
the World Food Program which then continued for years and become an important counter piracy project in that $\operatorname{area}^{28}()$. The resolution also followed up with the European Union Naval Force Somalia (EU NAVFOR Somalia) in purpose of secure the water lane near Somalia for ship and deliverance of food aid mission. In 2009, the US-led Combined Maritime Forces (CMF) established the Combine Task Force (CTF) 151 as the first international cooperation framework that focusing on combating sea piracy around the Gulf of Aden.

This international cooperation that focus on guarding the WFP ships, which has been targeted frequently, and increasing maritime security in the Horn of Africa water are believed by many expert as one of important measures in combating piracy in Somalia. ${ }^{29}$ Beside join military force in patrolling this area, another preventive action also design to be applied by the ship owners or companies and the ship operators. Best Management Practice for Protection against Somalia Based Piracy (BMP4) was circulated by the Maritime Safety Committee (MSC) providing complete information on piracy e.g. its methods, type of attacks, effective preventive action such as full sea speed to prevent the pirates to board the ship, also type of ship protection ${ }^{30}$. This document, according to Hodgkinson, brings a great contribution in mitigating the risk of piratical attack towards ships that travel trough that area.

${ }_{28}$ Hodgkinson, S.L. (2013). "Current Trends in Global Piracy: Can Somalia's Successes Help Combat Piracy in the Gulf of Guinea and Elsewhere". Case W. Res. J. Int'l L., 46, p.145.

29 Chalk. Op.Cit.

30 Best Management Practice for Protection against Somalia Based Piracy (BMP4), 2011.
Another counter piracy measure that claimed as the recent effective tactic is the involvement of private security guard that hired by the ship owner to protect the cargo as well as the $\mathrm{crew}^{31}$ of a vessel that sails trough high risk area such as off the Horn of Africa. The employment of private contracted armed security personnel (PCASP) has shown an impressive result with no successful piracy attacks towards arm-guarded ship has been recorded $^{32}$. Apparently, the presence of armed guards on board has created a great deterrence effect to the pirates ${ }^{33}$. However, despite the great contribution of private security companies to prevent piratical actions lately, its involvement remain in controversy considering PCASP role as a non-state actor with armed forces have not been regulated yet in international maritime framework ${ }^{34}$. As a result, many countries are still reluctant to granted permission to ship with armed guard to enter their territory since it might treat country's sovereignty.

\section{The rising number of piracy in Southeast Asia}

The climbing number of reported actual and attempted piracy and armed robbery in Southeast Asia is depicted by the data that released by the IMB with 141 reports received in 2014. Compare to Africa with 55 reports in the same year, this number illustrates the alarming situation in this region. However, since the data that released

31 Gould, A. (2015). "Global assemblages and counter-piracy: public and private in maritime policing". Policing and Society, pp.1-11.

32 McConnell, T. (2012). Somali Piracy Drives Security Boom. http://www.globalpost.com/dispatch/news/ regions/africa/120307/somali-piracy-drives-securityboom (December 27, 2015).

33 Hodgkinson. Op.Cit.

34 Gould. Op.Cit. 
by IMB does not divided the report based on its severity, the situation is probably less worrying considering the petty crime type of piracy of this region ${ }^{35}$. Based on the IMB Annual Report ${ }^{36}$, from 141 reports of actual and attempted piracy and armed robbery attacks in Southeast Asia, the actual attacks was 139 where 4 attacks occurred on berthed ships, 76 attacks on anchored ships, and 49 attacks towards ships on steaming. As one of the busiest route that connects Europe to Asia, the number of transit vessel along the Malacca Strait has reached its peak in 2014 with total 79,344 transits during that year ${ }^{37}$. In average, there were 217 vessels transit per day in this area with valuable cargo such as oil and liquid petroleum gas which attract the pirates alongside the strait.

In 2004, the cooperation to enhancing security on the region was started by the establishment of Malacca Strait Security Initiative (MSSI) between three littoral states around the Strait of Malacca, i.e. Indonesia, Malaysia, and Singapore, who agreed to involve in cooperated patrol called MALSINDO operation. This operation is believed to be a reaction towards United States' pressure demanding for security improvement in the strait $^{38}$. MALSINDO operation started with deployment of 17 ships ( 7 from Indonesia, 5 from Singapore, and 5 from Malaysia) to patrol within each own country territorial water. Beside the MALSINDO operation, trilateral cooperation on anti-piracy action also showed by the "Eye in the Sky" initiative to carry out

35 Bateman, S. Op.Cit.

36 IMB Annual Report, 2014. p.9

37 Nippon Maritime Center, cited in Hand, 2015.

38 Shie, 2007. maritime air patrol around Malacca Strait. In a greater scope, cooperation between countries in Asia to tackle sea piracy problems manifested trough the establishment of Regional Cooperation Agreement on Combating Piracy and Armed Robbery against Ships in Asia (ReCAAP).

This organization was initiated by Japan with aim to provide a platform for information exchange between participating countries, facilitate capacity building for member on combating piracy and armed robbery, and cooperate with other organization or party with the same objective. Before the MALSINDO operation and ReCAAP was formed, all three countries has already cooperated trough bilateral collaboration i.e. Indonesia-Malaysia and Indonesia-Singapore in improving maritime security on the region.

These multi-stages actions on combating and mitigating the risk of piracy attack in Southeast Asia seem to bring a great result for the security of the region. In Table 1 , it can be seen that the number of piratical attack in this area had decreased from 2004 with 158 reports to 47 reports in 2009. However, in 2010, the number of reports started to climb and the trend was continued to 2014 with 141 reports. There are some arguments emerged in order to explain this trend, such as the shifting of high piracy area from Strait of Malacca to South China Sea, eastward of Singapore, and Indonesia ports ${ }^{39}$ which indicated by the increase number of piracy attack reports that located in that area, i.e. Indonesia with 40 reports in 2010

\footnotetext{
39 Hribernik, M. 2015. Southeast Asia's Piracy Headache. http://thediplomat.com/2015/02/southeast-asias-piracy-headache/ (December 29, 2015).
} 
to 100 in $2014^{40}$. The fact that high number of piracy attacks conducted in Indonesia, it brings a great responsibility for Indonesia to strengthen its territorial security. However, with ineffective naval force to cover the vast maritime territory and another maritime crime which are urgently needed to tackle, such as illegal fishing, the task to eradicate sea piracy in cooperation with other countries has been left behind ${ }^{41}$.

The reluctance of littoral states around Malacca Strait to grant permission for armed private maritime security to enter their territory is based on the argument that PMSC is a threat to countries' sovereignty. ${ }^{42}$ Countries objection is based on the concern over the ability of PMSC to use force in delivering their duty, as it has potential to creates overlap of rights between PMSC and country's naval force when encounter with piracy attacks. Despite the International Code of Conduct for Private Security Service Providers has formulated the duty of the armed private maritime security, this self-regulatory document, according to Gould, is not sufficient to legislate the rights and duty of armed maritime private security. Unfortunately, rejection to PMSC involvement that does not followed by improvement in maritime securitization only construct a circumstance that facilitate more piratical attack, and this is the situation which believed by many experts currently happen in Indonesia. Considering the fact that the pirates in this region is shifting from jobless fisherman or cabin crew to well-organized career criminal $^{43}$, immediate

40 IMB Annual Report, 2014.

${ }^{41}$ Hodgkinson. Op.Cit.

42 Osnin, 2006.

43 Karsten von Hoesslin. (2012). "Piracy and Armed Robbery at Sea in Southeast Asia: Organized and Fluid". action should be taken by Indonesia and littoral countries in that region to combat the crime.

\section{CONCLUSION}

Piracy as one of crimes on the sea has created a huge threat to international trade that highly depended on sea transportation. The emerging of piracy hotbeds in Africa and Southeast Asia is mainly caused by countries' weakness and inability to firmly act against this crime. Global cooperation in form of join operation to secure the piracy's high risk area has shown a promising result in the Gulf of Aden. In Southeast Asia, despite the join patrol of MALSINDO had successfully reduce the number of crime in Malacca Strait, the piracy attacks report has continued to grow as the pirates move to South China Sea and Indonesia territory. In this stage, littoral countries in this area have a big responsibility to secure their water since they decided not to permit armed private maritime security to enter their territory. The role of PMSC in preventing sea piracy is relatively prominent reflecting to the result of its involvement in Gulf of Aden. However, as a new instrument in global security, there must be an international document to regulate its rights and responsibility that can be use as countries' guidance. International cooperation's contri-bution to the drop of global piracy should be highly appreciated. This positive trend of declining global piracy number must not lower international awareness of this crime as it has proven its ability to resiliently rise as it happens in Southeast Asia once it is given room.

Journal Studies in Conflict \& Terrorism, 35(7): 542-552 


\section{BIBLIOGRAPHY}

Abhyankar, J. (2006). Piracy, armed robbery, and terrorism at sea: a global and regional outlook. In: Ong-Webb, G. G. (ed). Piracy, Maritime Terrorism, and Securing the Malacca Straits. Singapore: Institute of Southeast Asian Studies Publishing.

Bateman, S. (2010). "Maritime piracy in the Indo-Pacific region-ship vulnerability issues". Maritime Policy \& Management, 37(7): 737-751.

Chalk, P. (2009). "Piracy off the horn of Africa: scope, dimensions, causes and responses". Brown J. World Aff., 16, p.89.

Clarke, R.V. (1983). Situational crime prevention: Its theoretical basis and practical scope. Crime and justice, 225-256.

Daxecker, U. and Prins, B. (2013). "Insurgents of the Sea Institutional and Economic Opportunities for Maritime Piracy". Journal of Conflict Resolution, 57(6): 940-965.

Farrell, G., Tilley, N. and Tseloni, A. (2014). Why the Crime Drop?. Why Crime Rates Fall and Why They Don't, p. 43.

Foster, B., (2014). "Modern maritime piracy: An overview of Somali piracy, Gulf of Guinea piracy and South East Asian piracy". British Journal of Economics, Management \& Trade, 4(8): 1251-72.

Gagain, M., (2010). "Neglected Waters: Territorial Maritime Piracy and Developing States: Somalia, Nigeria, and Indonesia”. New Eng. J. Int'l \& Comp. L., 16, p.169.
Gerrard Ong, G. (2005). Ship's can be dangerous, too: coupling piracy and terrorism in Southeast Asia's maritime security framework. In: Derek Johnson and Mark Valencia (eds). Piracy in Southeast Asia: Status, Issues, and Responses. Singapore: Institute of Southeast Asian Studies Publishing.

Gould, A. (2015). "Global assemblages and counter-piracy: public and private in maritime policing”. Policing and Society, pp.1-11.

Hodgkinson, S.L. (2013). "Current Trends in Global Piracy: Can Somalia's Successes Help Combat Piracy in the Gulf of Guinea and Elsewhere". Case W. Res. J. Int'l L., 46, p.145.

Hribernik, M. (2015). Southeast Asia's Piracy Headache. http://thediplomat. com/2015/02/southeast-asias-piracyheadache/ (December 29, 2015).

International Chamber of Commerce, IMB, Piracy and Armed Robbery against Ships Annual Report 2006, 2010, 2014.

Karsten von Hoesslin. (2012). "Piracy and Armed Robbery at Sea in Southeast Asia: Organized and Fluid". Journal Studies in Conflict \& Terrorism, 35(7): 542-552.

McConnell, T. (2012). Somali Piracy Drives Security Boom. http://www.globalpost.com/dispatch/news/regions/africa/120307/somali-piracy-drives-security-boom (December 27, 2015).

Munson, M. (2013). Nigeria is Not Somalia-Look for Pirates Somewhere Else. http://warontherocks.com/2013/12/nigeria-is-not-somalia-look-for-pirates- 
somewhere-else/ (Dec 25, 2015).

Orji, U.J. (2013). "Tackling Piracy and Other Illegal Activities in Nigerian Waters". Journal of Defense Resources Management, 2: 65-70.

Philip Gosse. (2012). The History of Piracy. New York: Courier Corporation.

Rosenberg, D., (2009). "The political economy of piracy in the South China Sea". Naval War College Review, 62(3): 43-58.

United Nation Convention of the Law of the Sea 1968.
United Nations Security Council. 2008. Resolution 1816: Security Council Resolution on Piracy off the Coast of Somalia (2 June 2008) [Online]. S/RES/1816(2008). [Accessed 27 December 2015]. Available from:http://www.un.org/Docs/journal/asp/ws.asp?m=S/RES/1816\%20 (2008)\%20

Young, A. J. (2007). Contemporary Maritime Piracy in Southeast Asia. Singapore: Institute of Southeast Asian Studies Publishing. 